\title{
CORPORATE SOCIAL RESPONSIBILITY (CSR) OF PR IN SYRIAN AND RUSSIAN TELECOMMUNICATION COMPANIES IN CRISIS. A COMPARATIVE ANALYTICAL STUDY ON COMMUNICATION ACTIVITIES OF MTN AND MTC COMPANIES
}

\author{
V.L. Muzykant, F. Mfarrej \\ Peoples' Friendship University of Russia \\ Miklukho-Maklaya str., 10/2, Moscow, Russia, 117198
}

The question of corporate social responsibility of public relations especially in crises continues to be timely, as highlighted by recent controversies on this topic. Coming to terms with cases such as these relies on the task of defining corporate social responsibility, and more broadly figuring out which aspects of the PR's social responsibility can be feasibly regulated.

This study aimed to identify the concept of corporate social responsibilityin crises for the public relations departments of MTN and MTS, and the activities and programs implemented by these two companies to reflect their concept of corporate social responsibility towards their publics and community.

Key words: corporate social responsibility, public relations, MTN, MTS, risk communication, issues management,press agentry, public information model, two-way asymmetrical model, two-way symmetrical model, social responsibility theory

Corporations around the world are struggling with a new role, which is to meet the needs of the present generation without compromising the ability of the next generations to meet their own needs. Organizations are being called upon to take responsibility for the ways their operations impact societies and the natural environment [1].

The concept of corporate social responsibility (CSR) is relatively modern in the scientific studies, but interests in the research of this concept and its applications began to increase and increase day by day in different scientific fields, especially in the administrative sciences and accounting [2]. As this concept and its applications are closely related to the concepts of public relations in private enterprises, there has been a growing interest in many private companies and organizations to make this concept and its applications a major public relations task [3].

The researchers and experts agree that the concept of corporate social responsibility includes all the decisions, actions, programs, activities and events of the organization towards both its internal and external publics, towards the local community and the environment in the context of its overall endeavor to connect itself to the community and work to develop it as much as possible [4]. There has been increasing interests in many private companies to make this concept and its applications a major public relations function. Some have even established corporate social responsibility units such as MTN in Syria, while other established a communication department and made the corporate 
social responsibility a special unit in this department, as it adopted by MTS in Russia which is the interest in this study.

"Mobile Telephone Network" (MTN), is a South Africa-based multinational mobile telecommunications company, operating in many African, European and Asian countries including Syria. Its head office is in Johannesburg. As of 30 June 2016, MTN recorded 232,6 million subscribers across its operations. MTN gas a wide set of products and services that includes cellular network access, internet and business solutions.

"Mobile TeleSystems" (MTS) is Russian telecommunications company as well providing services in Russia and CIS countries under the trademark "MTS". MTS provides cellular services (in GSM, UMTS (3G) and LTE), wireline telephony, broadband Internet access, mobile television, cable television, digital television and related services, in particular content sales services.

In general, the communication departments of both companies carry out all the communications activities with all segments of the company, "whether external or internal" [5].

The interest in studies of corporate social responsibility by researchers and universities is a necessity to keep up with the developments in the fields of companies and originations [6]. This study aspires to identify the term of corporate social responsibility in an important sector, namely the telecommunications sector that deals with all segments of society. It also aims to identify the aspects of corporate social responsibility in crises in this important sector compared to the concept aspects in two global companies, one in Syria and the other in Russia, which contributes to demystify the concept of corporate social responsibility. Its reflects on the work of private companies, particularly in determining its corporate social responsibility towards its publics, community and local and global environment, especially with the increasing questions and criticisms about the role of private companies towards the corporate social responsibility entrusted to them in society and the process of its development.

Therefore, the problem of this study is to identify the role of public relations department in MTN in Syria and MTS in Russia in the activities and practices that embody the concept of corporate social responsibility in crises. The problem revolves around the questions of: What is the concept of corporate social responsibility for the public relations departments of MTN and MTS? Furthermore, we will consider what activities and programs are implemented by these two companies to reflect their concept of corporate social responsibility towards their publics and community in crises.

The main objectives of this study are to define the concept of corporate social responsibility in crises of MTN in Syria and MTS in Russia through the corporate social responsibility programs of these two companies in the scope of publics, as well as to identify the role of public relations departments in defining the concept of corporate social responsibility and programs of these two companies. In addition, it aims to discover the nature of programs and activities adopted by these two companies in the embodiment of corporate social responsibility towards their publics, society and the environment in crises.

MTS and MTN are among the largest telecommunications services companies in Syria and Russia. They contribute significantly to the communication processes of various forms, which makes them a good sample to explore the study's problem. Therefore, the 
researcher chose a purposeful sample of public relations managers in MTS and MTN departments that perform the functions of public relations and corporate social responsibility in crises. He conducted structured interviews covering the question of corporate social responsibility, programs and activities.

The researcher took into consideration the social responsibility of MTN during the period of Syrian crisis. The crises facing organizations in the twenty-first century may be sudden or large. Their impact on these organizations may be considerable, which may lead to the suspension of their services or damage to their corporate reputation and image. Such crises are inherently complex in nature, since they may have technological, economic, political and social dimensions, which are reflected in the organization's staff or in the public that benefits from its services[7]. All this requires public relations specialists in organizations to play a strategic role in crises management that may occur to the organizations in which they work [8].

The study relied on a theory and a number of communication models.

First: The theory of corporate social responsibility, which emphasizes that the media must contribute to certain obligations towards society by respecting specific standards such as accuracy, objectivity and balance, since society has the right toward press to abide by high standards in the performance of its functions[9]. One of the foremost Communication scholars Denis McQuail summarized the basic principles of Social Responsibility Theory as the following [10]:

- Media should accept and fulfill certain obligations to society.

- These obligations are mainly to be met by setting high or professional standards of informativeness, truth, accuracy, objectivity and balance.

- The media should avoid offensive content triggering crime, violence, or civil disorder or harm tominority groups.

- The media as a whole should be pluralist and reflect the diversity of their society, giving access to various points of view and rights of reply.

Second: Gruning and Hunt's four models of PR practice. These different models draw clear boundaries to the optimal use of the public relations function in different organizations, thus increasing the importance of this function and applying it scientifically. These models are.

Press agentry model [11]: Information flows from the senior management to the employees or from the organization to its external publics in order to achieve publicity for the organization. Information is often misled to the public or relies on insufficient claims.

Public information model [12]: It relies on honestly and objectively providing information to the public, but the communication here remains one-way from the organization to its public.

The two-way asymmetrical model [13]: Communication in this model is a two-way approach from the organization to its public and vice versa, but it primarily seeks to serve the organization's objectives for the so-called artificial communication by changing the behavior of the publics in the short term.

The two-way symmetrical model [14]: It aims to make communication two ways and encourages dialogue between the organization and its public through a strategic relationship based on mutual understanding. The model includes an exchange of views and ideas 
between the two parties, leading to a change in the attitudes and behavior of the two parties. The two way symmetrical model is almost similar to the corporate social responsibility idea because of necessity of feedback with the target audience. When the communication chain is broken the realization into practice the CSR-concept is becoming a problem.

Linking this study to the theory of social responsibility and the symmetrical two-way public relations model shows that the responsibility of public relations towards its society in crises is inseparable from its basic work of persuasive communication. Hence, the asymmetrical model of the two ways shows that the organization is directed to its internal and external publics. It assumes that the organization's practice of public relations focuses on achieving mutual understanding at one level of importance. Hence, the information of the organization or the public is gathered on scientific basis [15].

The Study reached the following results.

1. Public Relations in both MTN and MTS is used as a strategic communication medium in crises to:

- Communicate with employees to respond to their demands and provide them with information and incentives.

- Communicate with the external publics to attract them to deal with the company and to inform them of its services and activities in the areas of social responsibility.

- Liaise with the Syrian and Russian legal and legislative bodies in the context of interest in government affairs.

- Contact other telecommunications companies in Syria and Russia to find out the conditions and aspirations of MTN and MTS's competitors.

2. The senior management of MTN in Syria and MTS of Russia are responsible for defining their strategies in the field of corporate social responsibility in crises. The role of the public relations department is to formulate policies and develop programs to translate these strategies into actual programs targeting publics and community.

While MTN's strategy focus on supporting sustainable community development in Syria with NGOs and encouraging small enterprises in communications, MTS in Russia is focusing on supporting cultural and sports activities, especially for young people.

3. The position of corporate social responsibility in the organizational structure of the two companies varies according to the recognition of the importance and role of this responsibility by the senior management in both companies. It occupies a middle position in MTS, although the company seeks to raise the level of activities that reflect its corporate social responsibility. It occupies a low position in MTN, as the department of public relations applies the activities of corporate social responsibility in a chronological manner according to the urgent developments and its impact on the company.

4. The activities and contributions of the public relations department in crises are very similar to the concept of corporate social responsibility in both companies. The study revealed that both MTN in Syria and MTS in Russia support cultural, developmental, health and sports programs. MTN focuses more on micro-enterprise support, internet outreach and drug control programs. MTS is also involved in leading initiatives in different business fields and environmental protection programs with discounted offers on national occasions and holidays. 
5. MTN in Syria and MTS in Russia are interested in the effective use of various media outlets in order to define their policies and their concept of corporate social responsibility in crises towards society and related activities.

According to the results of the interview conducted with MTN newspapers, mobile messages and Internet sites, were orderly ranked first, second and third. For MTS, brochures, websites and field visits ranked first, second and third respectively.

6. MTN's communication activities are a set of practices for the public relations within the organization as part of its promotional work to achieve the organization's goals and social responsibility and to improve its image among its internal and external publics in crises.

MTN's public relations to achieve its social responsibility is a scientific administrative communication activity, manifested in effective organization capable of accomplishing its tasks in crises through public relations in a body associated with MTN's senior management in crises; public relations is a communication activity characterized by flexibility of organization, which enables it to achieve the objectives of social responsibility and direct contact with both internal and external publics in crises; the nature of the communication activities required to achieve social responsibility is different, requires multiple skills and skilled communication and human relations staff to implement.

The communication activities used to achieve the public relations objectives of their social responsibility in crises in MTN are a set of activities that usepublic relations department hosts to target public of social responsibility programs to inform them and make them feel familiar with the MTN's activities. MTN prepares informative leaflet through its well-prepared website in terms of information, wording and liquidity. It is a general means to assist a public relations specialists to determine the public's scope of MTN activities and answers many of their key questions. Mobile messages: MTN prepares different mobile messages to target its publics to identify their social responsibility campaigns in crises.It is essential that the name and services of the organization remain relevant to the target publics and the best means are news, articles and statistics published in local newspapers. As the local press needs this kind of news, coverage of MTN's social responsibility activities and participation in its seminars, workshops and campaigns are all news that can be provided to the press. Radio and Television: MTN works to improve the role of its activities and services through participation in programs and seminars that are broadcasted on radio and television, thus enhancing its corporate reputation and image in crises. Posters: MTN uses two types of posters to highlight the name of the organization, and posters that serve the community and the organization by publishing their most prominent activities and the latest social responsibility campaigns such as the preparation of posters on violence against children, vaccination campaigns against certain diseases, health education and others. Press conferences activities of high value by inviting media professionals from the press, radio and television to cover these conferences. MTN traditionally prepares in advance to answer questions from journalists in crises. Preparation of films and short videos to introduce MTN's social responsibility activities.

7. As part of MTN's social responsibility in crises, public relations in the company is keen to play an effective and sufficient role in dealing with the Syrian crisis and its impact on the whole country through the following strategies. 


\section{Before the crisis:}

1) Investigate what is known as risk communication (Risk Communication) which is a branch of what is known in the field of communication and public relations as issues management.MTN provides a scientific base on environmental and health risks and provides reliable information to the public in a meaningful and understandable way. MTN's public relations take into account the issue of risk communication through:

- Encouraging senior management to be part of the organization's communication system.

- Selection of experts to be consultants in the organization.

- Taking care of the media and establish effective and sustainable relations with

- Conducting research about the views and feelings of the different publics dealing with the organization.

- Identifying strategic publics working with the organization.

2) Create an information center:

The mission of the center is to disseminate accurate and true information about the organization and to fight rumors. The center also sets a strategic plan to achieve its objectives and works normally when there is no crisis and is active when the crisis occurs. MTN also focuses on making this center enjoy credibility before the crisis, so when a crisis occurs, the publics of the organization receive what the center's officials say with truth and confidence.

Planning for a crisis in advance: MTN workings on predicting crises that may occur and plans to develop different scenarios on how to deal with them.

\section{During the crisis:}

MTN's public relations plays a crucial role during the crisis, because public relations officials are the link between the general administration and the affected or crisis-affected public, including the media. MTN's public relations during the crisis is committed to:

- Attention to the organization's public, which is a priority for it.

- Sense of heavy responsibility and commitment to solve the problem.

- Adhering to honesty and telling the truth, and adopting an open door policy in dealing with publics and media.

- Avoiding words that «no comment» or «there is nothing to say», because this aggravates the bad attitude toward the administration and the organization.

- Standardizing the speech language in the organization and avoiding more than one MTN's spokesperson.

- Using the information center effectively.

- Ensuring that the media and the publics are kept informed.

- Carefully studying various media and developing a plan to address what they broadcast about MTN.

\section{After the crisis:}

MTN's public relations is keen to assess what occurred, to identify strengths and weaknesses in its performance and to develop a contingency plan for future crises.

It also takes into account the commitment to work ethically and the promotion of corporate social responsibility. Therefore, in order to increase the effects of PR in achieving corporate social responsibility in crises, it's advisable that more attention should be paid 
by telecommunication companies to corporate social responsibility programs and activities that are related to the needs of publics and society according to the real priorities of their local communities. The worst situation is when in the press service of MTS the reasons for the failure very often are not commented.

Moscow subscribers of MTS report interruptions in the work of the mobile Internet. The malfunction in the work of the mobile Internet MTS users celebrate over the past few days. Vesti.Ru users reported that it was impossible to reach the MTS call center within a few hours. From the disconnection of the Internet, first of all, the motorists suffered, who use Internet services, informing about traffic jams. MTS subscribers on Internet forums and on the air of Moscow radio stations (in particular, City FM) discuss and give advice on how to cope with the problem. In particular, they propose to reconnect the service independently ... In MTS, however, they assure that there are no failures in the work. As Valery Kuzmenko, the press secretary of MTS, reported to Vesti.Ru, all services are working in the usual mode ... This may be an individual subscriber question ... [16].

Let's consider the situation in the Moscow on February 18, 2014 when because of a failure, subscribers had problems with dialing to the numbers of the network of Mobile TeleSystems. As several subscribers of various operators have told Interfax, it is difficult to call MTS subscribers' numbers, it is not possible at first attempt or at all. "The direction is overloaded" the Interfax correspondent heard in the phone of the city telephone when he tried to call his own mobile number. Meanwhile, a source familiar with the situation, told Interfax that the Moscow network of the MTS accident. According to him, the problems are fixed from about 15:30 Moscow time. In the press service of MTS the reasons for the failure were not commented [17].

One more case. The mobile operator has technical problems again of 28 of January in 2016: many people report that the operator's subscribers can not make calls. Technical queries and access to the Internet do not work - you can not find out your balance and check the connected services. About the problems reported by users from Khabarovsk, Irkutsk, Ulan-Ude and Penza. In the contact center of the operator, a mass failure does not confirm, but they apologize for the inconvenience and ask to leave an individual application for identifying the cause of the problem [18].

The delay of PR-spokesman's report with detailed analyses of the accident could cause comments like made by Alexey Bondarev in 2017, September 10: "Such lawlessness as I did not meet anywhere in the MTS. Without any reasons, explanations and warnings, block the subscriber number. This despite the fact that I need to work because of the constant communication. Wrote a claim-month said will be considered. I probably need to wait a month until they deign. After 5 days left Russia, they did not connect and did not explain anything to me. The remaining money in the account will be spent on charity. I will never advise anyone on this company. And wishing to use it, I will dissuade!" [19].

In Syria, sudden breakdowns of the telephone and internet services of MTN happened several times during the crises. For example, in 12 June 2014, most areas under the control of the Syrian government in the Syrian provinces witnessed almost total disruption of terrestrial and wireless communication networks and Internet networks for unknown reasons, while some servers remain in operation [20]. 
Sources in MTN claimed that telecommunications in Syria are witnessing a continuous deterioration at the level of interruptions and severe weakness, especially in the Internet networks via ADSL servers and other land connections.

The sources said that some private servers are still operating but very slowly, as a result of great pressure and increasing number of users, in light of the disruption of networks of MTN, especially in Damascus [21].

The sources explained that the problem has been going on for months, as the fees are paid to the company while its services are still poor and substandard. Syrian Ministry of Communications invariably invokes the failure of the submarine cable reaching Syria.

In this context also, the Syrian Telecom Company announced the repair of the submarine cable and its re-service, promising that thequality of Internet service will be normal soon.

The Syrian Telecommunications Company and MTN apologized for the delay in repairing the submarine cable for reasons beyond their control. They argued that the optical light cable coming from Alexandria was interrupted in the Mediterranean Sea and contacted the company responsible for repairing the cable [22].

No doubt, it's highly recommended that the Syrian and Russian companies allocate more corporate social responsibility programs to support independent scientific research, in addition to encourage scientific research in the departments of the companies themselves. All kinds of research are necessary to avoid problems caused by technical problems as well as communication breakdown like mentioned in Svetlana's comment "We previously did not have a coverage area for MTS (we had to communicate with other operators), in August we installed a tower near the MTS, we connected it at last, the connection was perfect, that the Internet is mobile, but since yesterday everything has disappeared again (and we were all overjoyed on Sims MTS (mobile) Just wanted to buy and for home WI-FI router MTS and sim-card, now I think that in vain, I do not need to do this" [19].

8. As it was above mentioned the two way symmetrical model is very close to the corporate social responsibility idea because of 24-hours feedback with the target public. Broken communication chain destroy the very roots of CSR-concept as it is shown in the following case. Interruptions with the MTS connection, according to residents of St. Petersburg, arose in several districts of the city and the region. Despite the fact that MTS on Twitter apologized to residents, a representative of MTS said that there was no increase in the number of calls to the MTS contact center. Such statements caused a storm of indignation among the subscribers of the mobile operator. On the AiF site forum: Maria160910: Nahals, left without a connection and are now being denied!!!; Konstantin12321: complete inaction! I'm sitting unconnected for 15 hours. Could explain on the site what the problem is; radasel: I've been sitting without communication for 4 hours, and they write that they are all right! On the site, MTS also does not have anything at all, everything is quiet and peaceful [23].

In conclusion, there is a need in MTN and MTS for more magazines, publications, books and statistics to the publics in order to raise awareness of social responsibility's programs or the members of the organizations themselves to inform them of the latest developments in their fields to effectively contribute to the upgrading of Syrian and Russian telecommunication companies in crises. 
Therefore, MTN and MTS can issue periodical, annual and non-annual corporate social responsibility reports according to the basis of organizational legal accounting and laws. Besides, there is an importance for the Syrian and Russian companies to allocate a clear and defined percentage of their profits to support corporate social responsibility activities in various fields.

Another suggestion is to work on the preparation and implementation of radio and television programs for Syrian and Russian telecommunication companies in cooperation with the concerned media to convey the organizations' message to the publics about their contributions to the realization of social responsibility's programs in crises, taking advantage of the possibilities of electronic and technological devices and their ability to influence.

\section{REFERENCES}

[1] Lopez M., Garcia A. \& Rodriguez L. (2007). Sustainable development and corporate performance: A study based on the Dow Jones Sustainability Index. Journal of Business Ethics. 75. 285-300.

[2] Malini M. (2006). Corporate social responsibility in emerging economies. Journal of Corporate Citizenship. 24. 20-22.

[3] Lewicka-Stralecka A. (2006). Opportunities and limitations of CSR in the post-communist countries: Polish case. Corporate Governance. 6(4). 440-448.

[4] Jenkins H. (2006). Small Business Champions for Corporate social responsibility. Journal of Business Ethics. 67. 241-256.

[5] Dulaimi Abdul Razzaq Mohammed. (2011). Public Relations and Human Engineering. Amman: Dar Al Masirah for Publishing, Distribution and Printing.

[6] Durrat Majali, Abd al-Bari Ibrahim Durrat \& Nabil Khalif al-Majali. (2010). Public Relations in the 21st Century: Theory and Practice: Systematic and Strategic Approach. Amman: Dar Wael Publishing and Distribution.

[7] Mackey A., Mackey T.B. \& Barney J.B. (2007). Corporate social responsibility and firm performance: Investor preferences and corporate strategies. Academy of Management Review. 32(3). 817-835.

[8] Tebo P.V. (2005). Building business value through sustainable growth. Research Technology Management. 48(5). 28-32.

[9] Heugens P. \& Dentchev N. (2007). Taming Trojan horses: Identifying and mitigating corporate social responsibility risks. Journal of Business Ethics. 75. 151-170.

[10] Black L.D. \& Hartel C.E.J. (2003). The five capabilities of socially responsible companies. The Journal of Public Affairs. 4. 125-144.

[11] Jamal Rasem Mahmood \& Ayad Khairat Moawad. (2005). Public Relations Department Strategic Approach. Amman: Dar Al Raya for Publishing and Distribution.

[12] Al-Jawhar Muhammad Naji. (2004). Public Relations: Principles and Applications, Contemporary Perspective. Cairo: Al-Qalam for Publishing and Distribution.

[13] Sultan Mohamed Sahib. (2011). Public Relations and Communication Means. Amman: Dar Al Masirah for Publishing, Distribution and Printing.

[14] Werther W.B. Jr. \& Chandler D.A. (2006). Strategic corporate social responsibility. New York: Sage Publications.

[15] Harbi Habas Raja. (2012). Public Relations and Senior Management Amman: Osama House for Publishing and Distribution.

[16] V moskovskoy seti MTS sboy, u abonentov problemy s dozvonom. URL: http://www.interfax.ru/ russia/359187 (date of access: 06.11.2017).

[17] V moskovskoy seti MTS sboy, u abonentov problemy s dozvonom. URL: http://www.interfax.ru/ russia/359187 (date of access: 06.11.2017). 
[18] URL: http://hleb.asia/news/2016/01/28/u-mts-proizosel-sboj-v-habarovske (date of access: 06.11.2017).

[19] Sboi u «MTS». URL: http://downdetector.ru/ne-rabotaet/mts (date of access: 06.11.2017).

[20] https://www.alaraby.co.uk/economy (date of access: 06.11.2017).

[21] https://www.igmena.org (date of access: 06.11.2017).

[22] https://mobile.almasdarnews.com/article (date of access: 06.11.2017).

[23] Kompaniya MTS izvinilas' v Tvitter za sboi svyazi v Peterburge i Lenoblasti. URL: http://www. pskov.aif.ru/society/education/764817 (date of access: 06.11.2017).

(C) Muzykant V.L., Mfarrej F., 2018

Article history:

Received: 2 December 2017

Revised: 22 December 2017

Accepted: 28 December 2017

For citation:

Muzykant V.L., Mfarrej F. (2018). Corporate social responsibility (CSR) of PR in Syrian ang Russian telecommunication companies in crisis. A comparative analytical study on communication activities of MTN and MTC companies. RUDN Journal of Studies in Literature and Journalism, 23 (1), 115-126. DOI 10.22363/2312-9220-2018-23-1-115-126

Bio Note:

Muzykant Valerii Leonidovich, Doctor of sociology, professor of Department of Mass communication, Peoples’ Friendship University of Russia. Contacts: e-mail: vmouzyka@mail.ru

Fadi Mfarrej, applicant of Department of Mass communication, Peoples' Friendship University of Russia. Contacts: e-mail: fadi.mfarej@hotmail.com

\title{
КОРПОРАТИВНАЯ СОЦИАЛЬНАЯ ОТВЕТСТВЕННОСТЬ (КСО) PR В СИРИЙСКИХ И РОССИЙСКИХ ТЕЛЕКОММУНИКАЦИОННЫХ КОМПАНИЯХ В УСЛОВИЯХ КРИЗИСА. СРАВНИТЕЛЬНЫЙ АНАЛИЗ ДЕЯТЕЛЬНОСТИ КОМПАНИЙ МТН И МТС
}

\author{
В.Л. Музыкант, Фади Мфарредж \\ Российский университет дружбы народов \\ ул. Миклухо-Маклая, 10/2, Москва, Россия, 117198
}

\begin{abstract}
Цель статьи - изучение вопроса корпоративной социальной ответственности PR в кризисных ситуациях, остающегося актуальным, о чем свидетельствуют дискуссии по данной теме. Признавая наличие подобных ситуаций, авторы считают, что важно определить задачи, стоящие перед корпоративной социальной ответственностью, выяснить, какие аспекты социальной ответственности PR могут быть осуществимо регламентированы. Это исследование предназначается отделам по связям с общественностью телекоммуникационных компаний
\end{abstract}


МТН и МТС для определения концепции корпоративной социальной ответственности в кризисных ситуациях. В материале проанализирован план мероприятий и программ, осуществляемых этими двумя компаниями в целях понимания их концепций корпоративной социальной ответственности перед их общественностью и сообществом.

Ключевые слова: корпоративная социальная ответственность, общественные отношения, MTN, MTC, коммуникация с рисками, управление проблемами, четыре модели PR, прессагентство, модель общественной информации, двухсторонняя асимметричная модель, двухсторонняя симметричная модель, теория социальной ответственности

\section{СПИСОК ЛИТЕРАТУРЫ}

[1] Lopez M., Garcia A. \& Rodriguez L. (2007). Sustainable development and corporate performance: A study based on the Dow Jones Sustainability Index. Journal of Business Ethics. 75. 285-300.

[2] Malini M. (2006). Corporate social responsibility in emerging economies. Journal of Corporate Citizenship. 24. 20-22.

[3] Lewicka-Stralecka A. (2006). Opportunities and limitations of CSR in the post-communist countries: Polish case. Corporate Governance. 6(4). 440-448.

[4] Jenkins H. (2006). Small Business Champions for Corporate social responsibility. Journal of Business Ethics. 67. 241-256.

[5] Dulaimi Abdul Razzaq Mohammed. (2011). Public Relations and Human Engineering. Amman: Dar Al Masirah for Publishing, Distribution and Printing.

[6] Durrat Majali, Abd al-Bari Ibrahim Durrat \& Nabil Khalif al-Majali. (2010). Public Relations in the 21st Century: Theory and Practice: Systematic and Strategic Approach. Amman: Dar Wael Publishing and Distribution.

[7] Mackey A., Mackey T.B. \& Barney J.B. (2007). Corporate social responsibility and firm performance: Investor preferences and corporate strategies. Academy of Management Review. 32(3). 817-835.

[8] Tebo P.V. (2005). Building business value through sustainable growth. Research Technology Management. 48(5). 28-32.

[9] Heugens P. \& Dentchev N. (2007). Taming Trojan horses: Identifying and mitigating corporate social responsibility risks. Journal of Business Ethics. 75. 151-170.

[10] Black L.D. \& Hartel C.E.J. (2003). The five capabilities of socially responsible companies. The Journal of Public Affairs. 4. 125-144.

[11] Jamal Rasem Mahmood \& Ayad Khairat Moawad. (2005). Public Relations Department Strategic Approach. Amman: Dar Al Raya for Publishing and Distribution.

[12] Al-Jawhar Muhammad Naji. (2004). Public Relations: Principles and Applications, Contemporary Perspective. Cairo: Al-Qalam for Publishing and Distribution.

[13] Sultan Mohamed Sahib. (2011). Public Relations and Communication Means. Amman: Dar Al Masirah for Publishing, Distribution and Printing.

[14] Werther W.B. Jr. \& Chandler D.A. (2006). Strategic corporate social responsibility. New York: Sage Publications.

[15] Harbi Habas Raja. (2012). Public Relations and Senior Management Amman: Osama House for Publishing and Distribution.

[16] V moskovskoy seti MTS sboy, u abonentov problemy s dozvonom. URL: http://www.interfax.ru/ russia/359187 (дата обращения: 06.11.2017).

[17] V moskovskoy seti MTS sboy, u abonentov problemy s dozvonom. URL: http://www.interfax.ru/ russia/359187 (дата обращения: 06.11.2017).

[18] URL: http://hleb.asia/news/2016/01/28/u-mts-proizosel-sboj-v-habarovske (дата обращения: 06.11.2017).

[19] Sboi u «MTS». URL: http://downdetector.ru/ne-rabotaet/mts (дата обращения: 06.11.2017).

[20] The New Arab. URL: https://www.alaraby.co.uk/economy (дата обращения: 06.11.2017).

[21] Bringing voices together. URL: https://www.igmena.org (дата обращения: 06.11.2017). 
[22] Syria. URL: https://mobile.almasdarnews.com/article (дата обращения: 06.11.2017).

[23] Kompaniya MTS izvinilas' v Tvitter za sboi svyazi v Peterburge i Lenoblasti. URL: http://www. pskov.aif.ru/society/education/764817 (дата обращения: 06.11.2017).

\section{История статьи:}

Дата поступления: 30 октября 2017

Дата принятия к печати: 1 декабря 2017

\section{Для цитирования:}

Музыкант В.Л., Мфарредж Фади. Корпоративная социальная ответственность (KCO) PR в сирийских и российских телекоммуникационных компаниях в условиях кризиса. Сравнительный анализ деятельности компаний МТН и МТС // Вестник российского университета дружбы народов. Серия: Литературоведение. Журналистика. 2018. Т. 23. № 1. С. 115-126. DOI 10.22363/2312-9220-2018-23-1-115-126

\section{Сведения об авторах:}

Музыкант Валерий Леонидович, доктор социологических наук, профессор кафедры массовой коммуникации Российского университета дружбы народов. Контактная информация: e-mail:vmouzyka@mail.ru

Мфарредж Фади, соискатель департамента массовой коммуникации Российского университета дружбы народов. Контактная информация: e-mail: fadi.mfarej@hotmail.com 